\title{
(2)
}
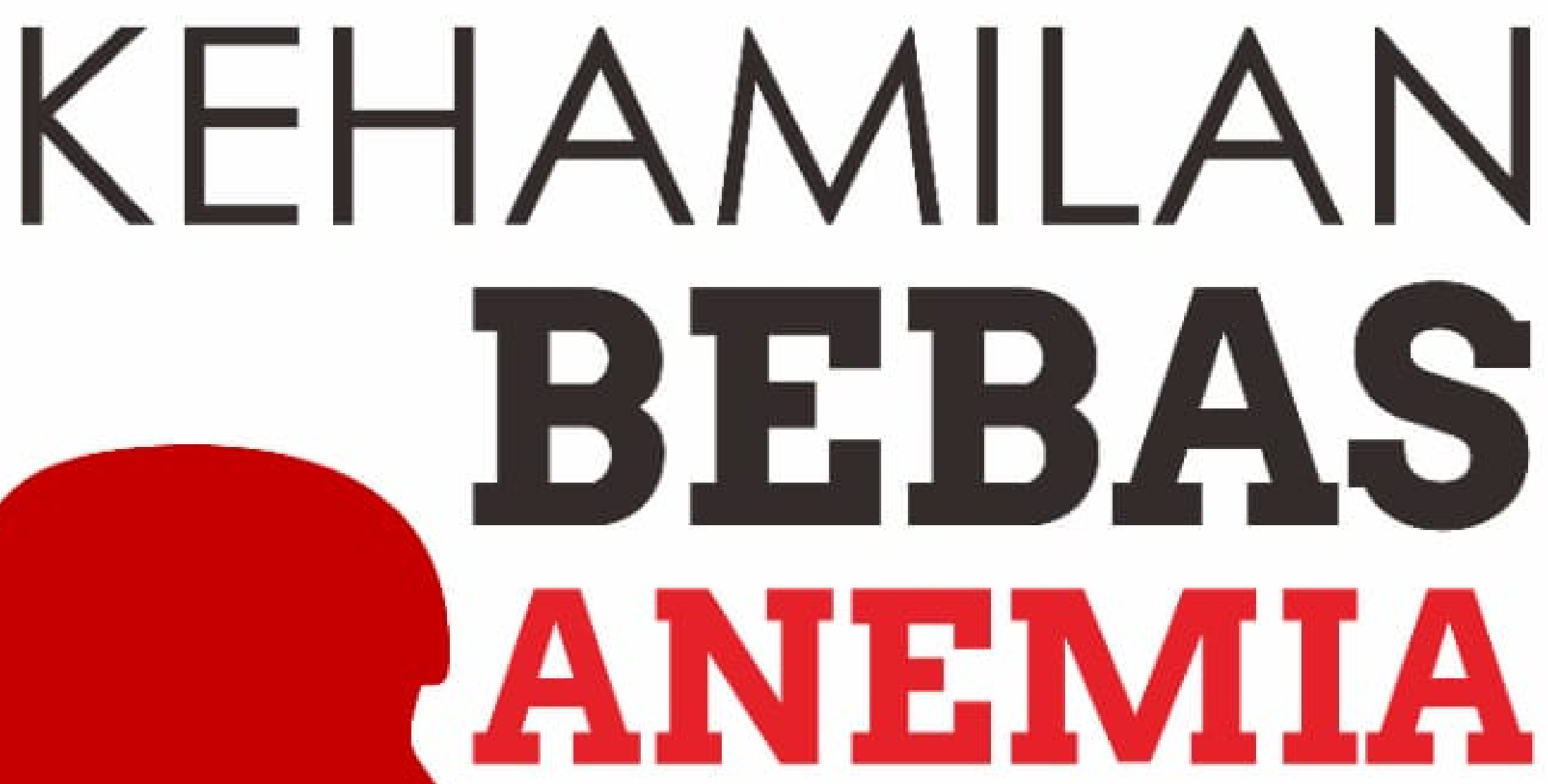

Pendekatan Menggunakan Information Motivation Behavior (IMB) Skill Model

Apri Sulistianingsih. S.ST., M.Keb Nurwinda Saputri. S.ST., M.Keb
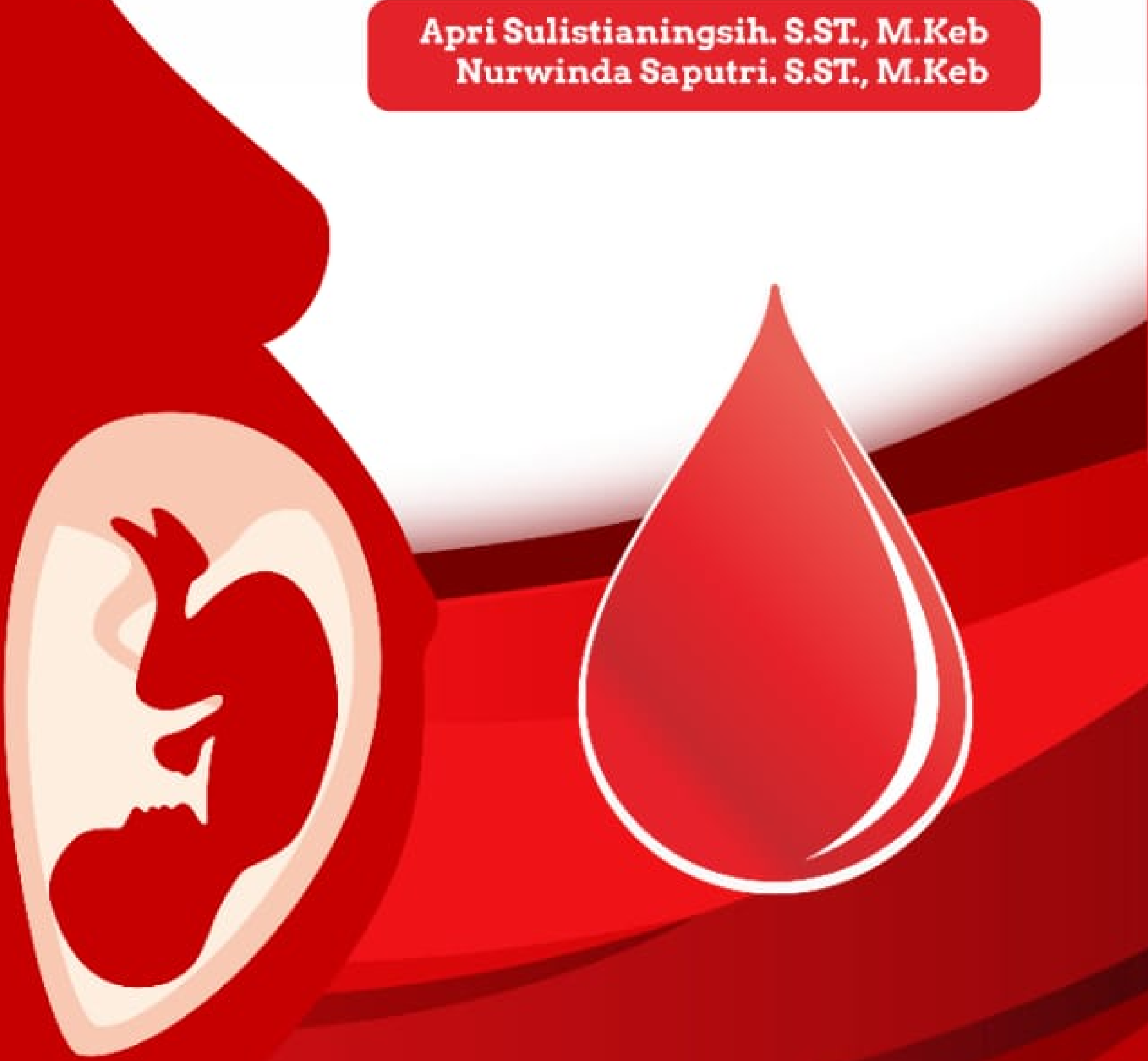


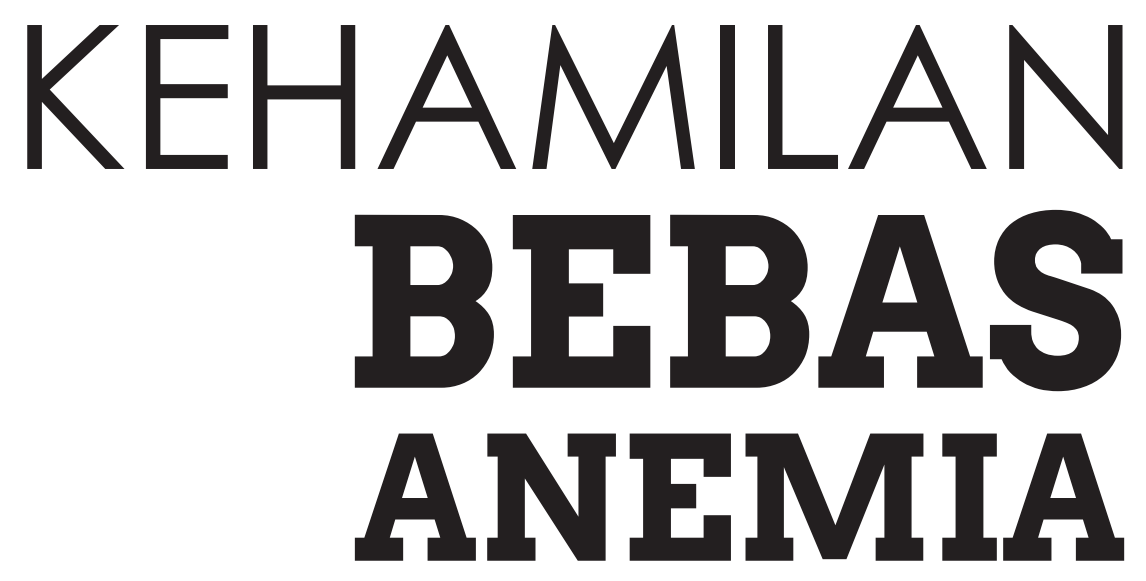

Pendekatan Menggunakan Information Motivation Behavior (IMB) Skill Model

Apri Sulistianingsih. S.ST., M.Keb Nurwinda Saputri. S.ST., M.Keb

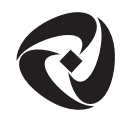

ERKA 


\section{Kehamilan bebas anemia : pendekatan menggunakan information motivation behavior (IMB) skill Model}

Penulis:

Apri Sulistianingsih. S.ST., M.Keb

Nurwinda Saputri. S.ST., M.Keb

Editor: Anton Tri Hasnanto. M.Pd

Penyunting: Dzul Istiqomah Hasyim. S.ST., M.Kes

Desain Sampul dan Tata Letak: N Hadi Wibowo

Ukuran: 15,5 x $23 \mathrm{Cm}$

Halaman: VIII + 112 Halaman

Tahun Terbit : 2020

Penerbit: Rumahkayu Pustaka

ISBN: 978-602-0738-31-4

Redaksi:

CV. Rumahkayu Pustaka Utama

Jl. Bukittinggi Raya, no. 758

Kelurahan Surau Gadang, Kecamatan Nanggalo, Padang.

kodepos 25146. telpon (o751) 4640465

instagram: rumahkayupustaka

twitter: rumahkayupustaka

facebook: rumahkayu pustaka

email: redaksirumahkayu@gmail.com

website rumahkayupustaka.com 


\section{KATA PENGANTAR}

Assalamualaikum warahmatullahi wa barakatuh

Alhamdullillah, segala puja dan puji bagi Allah SWT atas kaberkahan yang telah diberikan, sehingga monografl ini dapat diselesaikan dengan baik, shalawat serta salam selalu tercurah kepada Rasul junjungan, Nabi Muhammad SAW beserta keluarganya semoga kita mendapatkan saf'atnya diyaumil kiamah nanti, aamiin. Modul ini bertujuan untuk membantu petugas kesehatan/pelajar/mahasiswa dalam penatalaksanaan tentang anemia dengan pendekatan perubahan perilaku ibu Penulis meyakini bahwa monograf ini masih jauh dari sempurna, hingga terbuka untuk mendapatkan kritik dan saran untuk perbaikan pada semua sisi penulisannya.

Wassalamualaikum warahmatullahi wa barakatuh.

Pringsewu, Penulis 


\section{Daftar Isi}

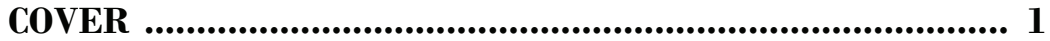

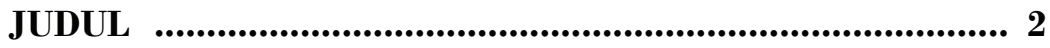

KATA PENGANTAR ........................................................... 3

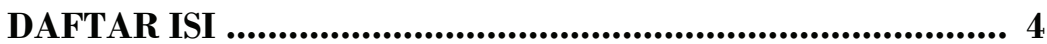

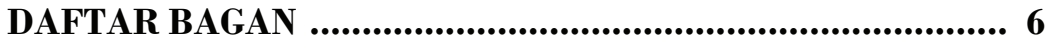

DAFTAR GAMBAR ........................................................ 7

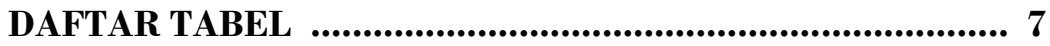

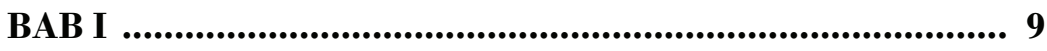

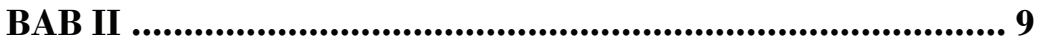

1. PENDAHUUAN ................................................... 9

2. Keterampilan Pendidikan Nutrisi pada Tenaga Kesehatan ........................................................... 12

A. Pendidikan Kesehatan ..................................... 12

B. Pendidikan berdasarkan Information Motivation Behavior Skill (IMB) Model ....... 17

C. Refrensi ................................................... 23

3. Informasi Kebutuhan Nutrisi pada Kehamilan ........ 24

A. Defisnisi ............................................................. 24

B. Tujuan ................................................................ 24

C. Materi yang Dikembangkan .............................. 25

D. Teknis Pelaksanaan .......................................... 43

E. Refrensi ...........................................................44

4. Informasi Anemia pada Kehamilan ........................... 48

A. Defisnisi ....................................................48

B. Tujuan ................................................................ 48

C. Materi yang Dikembangkan ................................ 48

D. Teknis Pelaksanaan ......................................... 60

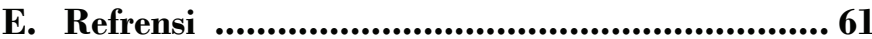

5. Informsai Manajemen Anemia Pendekatan dari Asupan Makanan ...................................................... 64

A. Defisnisi ...........................................................64 64

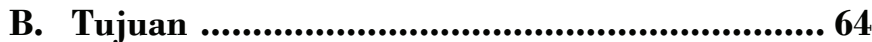

C. Materi yang Dikembangkan .............................. 65

D. Teknis Pelaksanaan ....................................... 70

E. Refrensi ................................................... 72

6. Informasi Manajemen Anemia Pendekatan Suplemen TTD ................................................. 75

A. Defisnisi ............................................................ 75 
B. Tujuan ................................................................. 75

C. Materi yang Dikembangkan ................................ 76

D. Teknis Pelaksanaan ........................................... 90

E. Refrensi ......................................................91

7. Motivasi Manajemen Anemia dengan Pendekatan Pemenuhan Nutrisi Kehamilan ............................. 93

A. Defisnisi ................................................................. 93

B. Tujuan …............................................................... 93

C. Materi yang Dikembangkan ............................. 93

D. Teknis Pelaksanaan .......................................... 98

E. Refrensi ........................................................... 99

8. Keterampilan Manajemen Anemia dengan Pendekatan Nutrisi dari Makanan dan Suplemen TTD ......................................................................... 102

A. Defisnisi .............................................................. 102

B. Tujuan ........................................................... 102

C. Materi yang Dikembangkan ............................ 103

D. Teknis Pelaksanaan ........................................ 110

E. Refrensi ........................................................ 111 


\section{Daftar Bagan}

Bagan 1: Kerangka Perilaku Kesehatan berdasarkan Information Motivation Behavior (IMB) Skill Model ............................................................ 11 


\section{Daftar Gambar}

\begin{tabular}{|c|c|}
\hline Gambar 1 & $\begin{array}{l}\text { Makanan } \\
\text { karbohidrat }\end{array}$ \\
\hline Gambar 2 & Makanan yang mengandung protein \\
\hline Gambar 3 & $\begin{array}{l}\text { Peningkatan Kebutuhan Besi Untuk Ibu } \\
\text { Hamil Dan Pertumbuhan Janin }\end{array}$ \\
\hline Gambar 4 & $\begin{array}{l}\text { Grafik Peningkatan Kebutuhan Besi } \\
\text { Menurut Bothwell }\end{array}$ \\
\hline Gambar 5 & $\begin{array}{l}\text { Grafik peningkatan kebutuhan besi } \\
\text { menurut Kemenkes } 2005\end{array}$ \\
\hline Gambar 6 & Sumber Makanan Yang Mengandung Besi \\
\hline Gambar 7 & Kebutuhan Tablet Fe \\
\hline Gambar 8 & Manfaat Konsumsi TTD Secara Teratur \\
\hline Gambar 9 & $\begin{array}{l}\text { Perbandingan Sel Darah Merah Normal } \\
\text { Dan Anemia }\end{array}$ \\
\hline Gambar 10 & Gejala Anemia \\
\hline Gambar 11 & Proses Deplesi Besi pada Kejadian Anemia \\
\hline Gambar 12 & $\begin{array}{l}\text { Proses produksi sel darah merah dari } \\
\text { sumber makanan }\end{array}$ \\
\hline Gambar 13 & $\begin{array}{l}\text { Risiko Kematian Bayi Terhadap Kadar } \\
\text { Hemoglobin }\end{array}$ \\
\hline Gambar 14 & Bahaya Anemia pada Ibu \\
\hline Gambar 15 & $\begin{array}{l}\text { Makanan yang Mengandung Besi dan } \\
\text { Penyerapannya }\end{array}$ \\
\hline Gambar 16 & keyakinan yang salah pada TTD \\
\hline Gambar 17 & $\begin{array}{l}\text { Perbedaan pemeriksaan kadar hemoglobin } \\
\text { dan tekanan darah }\end{array}$ \\
\hline Gambar 18 & Penatalaksanaan Efek Samping \\
\hline Gambar 19 & $\begin{array}{l}\text { Dampak minum dan tidak minum TTD } \\
\text { secara teratur }\end{array}$ \\
\hline Gambar 20 & Penatalaksanaan Anemia \\
\hline Gambar 21 & $\begin{array}{l}\text { Ibu hamil harus makan kaya mikronutrisi } \\
\text { dengan cara makan beraneka ragam jenis }\end{array}$ \\
\hline Gambar 22 & $\begin{array}{l}\text { Agar Nutrisi Makanan untuk Penyerapan } \\
\text { Besi Terjaga }\end{array}$ \\
\hline Gambar 23 & $\begin{array}{l}\text { contoh kombinasi makanan yang benar } \\
\text { dan yang salah }\end{array}$ \\
\hline Gambar 24 & $\begin{array}{l}\text { Pengaturan Konsumsi Makanan dan TTD } \\
\text { pada Ibu hamil }\end{array}$ \\
\hline
\end{tabular}




\section{Daftar Tabel}

Tabel 3.1 Rekomendasi Peningkatan Berat Badan Dan 26 Kebutuhan Nutrisi Selama Kehamilan

Tabel 3.2 Kebutuhan Nutrisi Selama Kehamilan 29

Tabel 3.3 Faktor Penghambat dan Penguat Penyerapan 36 Besi Non Heme (nabati)

Tabel 3.4 Jumlah Porsi Harian Ibu Hamil Berdasarkan 37 Pedoman Gizi Seimbang

Tabel 4.1 Kriteria Anemia pada ibu hamil berdasarkan 50 WHO

Tabel 5.1 Bahan Makanan yang Kaya akan Besi 69

Tabel 8.1 Jumlah Prosi Harian Ibu Hamil Berdasarkan 103 Pedoman Gizi Seimbang 


\section{PENDAHULUAN}

Mengapa Information Motivation Behavior (IMB) Skill

Model Sebagai Kerangka Model Pendidikan Kesehatan Nutrisi dan Suplementasi Besi Pada Ibu Hamil Menjadi Penting?

Fenomena tingginya kejadian anemia pada ibu hamil terlihat dari data World Health Organization (WHO) tahun 2005 sebesar 41,8\% dan sekitar 75\% berada di negara berkembang. Di Indonesia kondisi tingginya prevalensi anemia dapat dilihat dari laporan Riset Kesehatan Dasar (Riskesdas) dengan hasil 37,1\%.Penelitian Koura (2012) dan Kalaivani (2009) bahwa anemia dapat menyebabkan hasil luaran persalinan yang buruk seperti terjadinya gangguan aktivitas ibu hamil, perdarahan, gangguan pertumbuhan janin, berat bayi lahir rendah (BBLR) sampai pada kematian ibu dan dan bayi.

Mariyam tahun 2007, mendapatkan bahwa perilaku ibu hamil mengkonsumsi makanan yang mengandung energi, karbohidrat, protein, lemak, dan besi masih di bawah rata - rata rekomendasi Depkes RI tahun 1998 terutama asupan besi dari makanan baru terpenuhi $34,35 \%$. Rendahnya asupan besi ini juga disebabkan karena keluarga dengan status ekonomi rendah hanya mampu membeli makanan dari sumber nabati (besi yang tergolong non-heme) yang bioavaibilitasnya rendah serta mudah terganggu oleh faktor penghambat dan penguat penyerapan. Oleh 
sebab itu perlu dicari alternatif lain untuk penatalaksanaan anemia dengan meningkatkan asupan pengikat hemoglobin baik dari pola diet dan juga meningkatkan pola kepatuhan konsumsi TTD dengan memberikan pendidikan kesehatan yang meningkatkan pengetahuan, motivasi dan keterampilan ibu.

Pendidikan Kesehatan tersebut dilakukan secara berkala agar dapat mencegah lupa dan menguatkan motivasi dan keterampilan ibu dalam memperbaiki asupan makanan dan meningkatkan kepatuhan konsumsi TTD. Pendidikan kesehatan tersebut dapat dibangun berdasar kajian teori information motivation behavioral Skills (IMB) model yang dikembangkan oleh Fisher pada tahun 1992-2000.

Modul ini tentang Pendidikan Nutrisi Berdasar Information Motivation Behavior Skill (IMB) Model merupakan pedoman pelaksanaan pendidikan nutrisi pada ibu hamil anemia Ringan dan Sedang melalui IMB Model. Model IMB ini di rancang untuk mempermudah pendidikan kesehatan berdasarkan kajian teori dan penelitian yang menyebutkan faktor determinan kesehatan adalah informasi, motivasi dan keterampilan perilaku. Dalam model ini dapat dijelaskan bahwa seseorang akan berperilaku secara rasional berdasarkan informasi yang diperoleh. Namun tidak semua informasi yang diperoleh adalah benar, oleh sebab itu pemberian informasi yang tepat sangat diperlukan dalam pendidikan kesehatan.

Informasi dan motivasi dapat mempengaruhi perilaku secara langsung. Motivasi termasuk pada sikap dan kepercayaan tentang keterampilan dan 
perilaku seseorang. Pada dasarnya, keterampilan dan kepercayaan diri berguna untuk meningkatkan seseorang dalam menggunakan informasi dan mengembangkan kepercayaan dan sikap yang benar.

Dibawah ini merupakan dasar pelaksanaan kegiatan pendidikan Nutrisi pada Ibu Hamil Anemia :

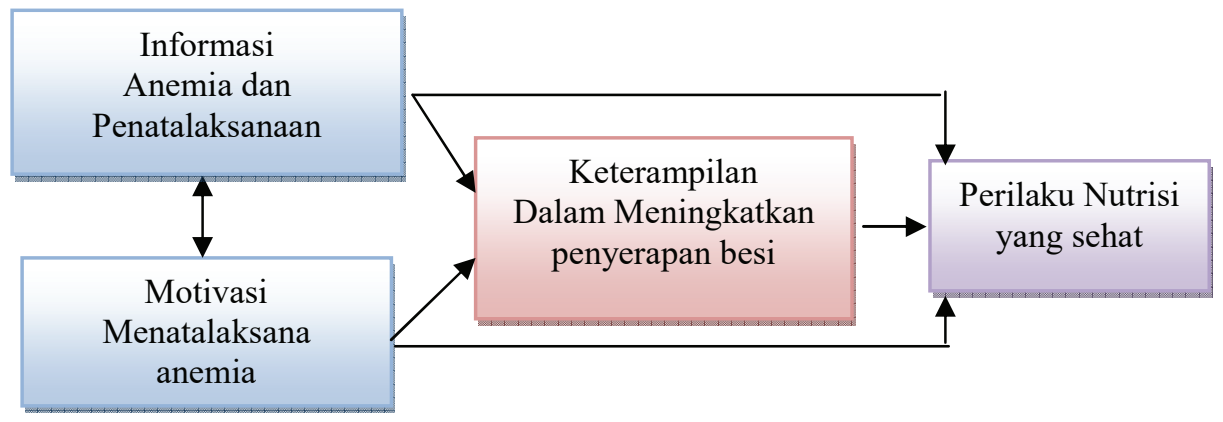

Bagan 1: Kerangka Perilaku Kesehatan berdasarkan Information Motivation Behavior (IMB) Skill Model

Modul ini bertujuan untuk membantu petugas kesehatan/pelajar/mahasiswa dalam penatalaksanaan tentang anemia dengan pendekatan perubahan perilaku ibu yang didasari oleh perubahan pengetahuan tentang nutrisi, motivasi ibu untuk menjaga kehamilannya dan keterampilan dalam memilih dan mengkombinasikan bahan makanan agar penyerapan besi baik dari sumber makanan maupun TTD dapat lebih maksimal. 
Tenaga Kesehatan dapat memberikan pendidikan kesehatan pada kelompok kecil 3 atau 4 orang atau seorang ibu hamil anemia.

\section{A. Pendidikan Kesehatan}

Pendidikan kesehatan menurut Commitee President on Health Education tahun 1997 adalah proses dalam menjembatani kesenjangan antara informasi kesehatan dan praktik kesehatan, memotivasi seseorang untuk mendapatkan informasi dan berperilaku yang dapat mencegah perilaku berisiko dan membentuk perilaku yang menguntungkan.

Tenaga Kesehatan berperan penting dalam pendidikan kesehatan pada ibu hamil khususnya yang menderita anemia. Keterampilan pendidikan kesehatan dapat membantu ibu hamil dalam memperbaiki pola nutrisi untuk penatalaksanaan anemia.

\section{Mendengarkan dan Belajar}

\section{Mendengar aktif}

a. Tenaga Kesehatan bersungguh sungguh mendengarkan dan memahami 
b. Tenaga Kesehatan aktif mengkonfirmasi apa yang dihami sebelum bereaksi terhadap apa yang ibu hamil sampaikan

c. Tenaga Kesehatan hendaknya tidak mengucapkan pendapat pribadi

Untuk ibu hamil, terkadang menyampaikan pengalamannya dan perasaanya dalam kalimat dan didengarkan dapat menjadi kesulitan yang perlu di atasi

\section{Bahasa Tubuh- Komunikasi Non Verbal}

Bahasa tubuh dapat menunjukkan ketertarikan Tenaga Kesehatan dan ibu hamil untuk mengatasi masalah anemia. Bahasa tubuh dapat ditunjukkan diantaranya adalah : mengangguk, kontak mata, duduk berhadapan, sentuhan, merasa sama, tidak terburu-buru.

Ibu hamil tahu bahwa dirinya merasa didengarkan oleh sebab itu Tenaga Kesehatan perlu menunjukkan ketertarikannya terhadap apa yang perlu disampaikan :

a. Nada suara yang lembut, dan memperhatikan

b. Gerak tubuh seperti mengangguk dan tersenyum

c. Respon sederhana seperti " benarkah?" "Ya"

\section{Bertanya dengan Pertanyaan Terbuka}

Memberi pertanyaan terbuka dapat memancing ibu hamil untuk bercerita lebih. Terkadang jika seseorang sudah menjelaskan 
kondisinya, Tenaga Kesehatan akan memulai memahami situasi dengan lebih baik.

\section{Contoh :}

a. "Apakah ibu selama hamil makan makanan bergizi?"

Jawaban dari pertanyaan tersebut hanya "ya" dan "tidak", jadi dengan pertanyaan tertutup ibu tidak akan menjelaskan lebih lanjut

b. "Bagaimana pola makan ibu selama kehamilan?"

Untuk menjawab pertanyaan Tenaga Kesehatan, ibu hamil harus memberikan informasi lebih melalui pertanyaan terbuka.

Berhati-hati dengan menggunakan pertanyaan "mengapa" karena kalimat tersebut bila tidak menggunakan intonasi yang tepat dapat bersikap menghakimi.

\section{Hindari Menggunakan Bahasa yang Menghakimi (Judge)}

Kalimat menghakimi seperti : benar, salah, ya, buruk, bagus, cukup dan tepat. Jika digunakan dalam kalimat pertanyaan dapat membuat ibu hamil merasa salah terhadap apa yang dilakukannya, dan akan membuat ibu khawatir dengan janin yang dikandungnya.

\section{Contoh:}

Menghakimi: apakah ibu memasak dengan sayuran dengan baik? 
Tidak menghakimi : Bagaimana ibu memasak sayuran?

Pada ibu hamil yang merasa terhakimi akan berdampak pada:
a. ibu akan bersikap defensif
b. Berhenti untuk bicara dan mendengarkan Tenaga Kesehatan
c. Khawatir dan tidak percaya diri

\section{Mengulang Kembali}

Mengulang kembali apa yang ibu hamil ucapkan adalah cara Tenaga Kesehatan untuk menunjukkan dirinya mendengarkan dan mengikuti apa yang ibu hamil sampaikan. Hal ini dapat lebih menguatkan ibu hamil dan menyatakan subjek masalah anemianya.

Tenaga Kesehatan dapat menyatakan kembali apa yang ibu hamil sampaikan, tetapi dengan cara yang berbeda dan lebih singkat. Tenaga Kesehatan tidak perlu mengulang kembali seluruh pernyataan tapi hanya pada poin penting saja.

\section{Contoh:}

Ibu hamil : Selama hamil saya kurang nafsu makan

Tenaga Kesehatan : apakah ibu merasa susah makan sejak awal kehamilan?....

Ibu hamil : Ya benar, saya mencoba beberapa makanan..... 